Кулик М.В., к. е. н., дои.. Київський національний торговельно-економічний університет, м. Київ, Україна Google Scholar https://scholar.google.com.ua/citations?hl=ru\&user=sfoM3m8AAAAJ\&view

\title{
МІЖКУЛЬТУРНА КОМУНІКАЦІЯ В ТУРИЗМІ
}

Визначним інструментом формування ефективної взаємодії між суб'єктом надання послуг і споживачем в туризмі $є$ побудова спільної системи комунікацій, яка певним чином визначає людські стосунки як за межами, так і всередині організації. Міжкультурна комунікація в процесі надання послуг в туризмі проявляється через взаємодію і взаємозв'язок між задоволеністю туристів (емоційне задоволення, задоволення соціального середовища) і акультурацію (інтеграцію, асиміляцію) [1]. Найбільш адаптивним до застосування у практиці підприємств в сфері туризму будуть такі методи налагодження міжкультурних комунікацій:

- для підвищення задоволеності туристів, як кінцевої мети туризму варто підвищувати ступінь позитивних емоцій та покращувати емоційний стан, що формується після того, як індивід отримує послугу;

- впровадження адекватної системи акультурації, ціллю якої повинно стати не нав'язування і підтримка культурних цінностей країни перебування, а пошук, виявлення й аналіз критеріїв $з$ метою подальшої взаємодії з іншими культурами;

- формування та підтримка культурної інтеграції, які вимагають збереження як культурних особливостей, так і створення нових культур.

Для підвищення задоволеності туристів варто створити умови, в яких відвідувачі почувають себе щасливими, цінними і корисними. Для цього доцільно налагодити обмін інформацією і підтримувати зворотний зв'язок між туристами і персоналом, а саме, поширювати серед відвідувачів інформацію про стан і перспективи розвитку дестинації, довготермінові цілі щодо вдосконалення інфраструктури i умов перебування в країні [2].

В процесі культурної адаптації складається здійснюється процес прийняття рішення або щодо підтримки культурних цінностей та 
особливостей країни походження, або щодо підтримки відносин 3 місцевим населенням.

Акультурація, в свою чергу, передбачає наступні типи комунікаційних зв'язків, як інтеграція, асиміляція, поділ і маргіналізація на рівнях емоцій, дій, та пізнання.

Формування системи міжкультурних комунікацій найчастіше ініціюється формальними лідерами (керівництвом компанії) чи, що буває значно рідше - неформальними. Тому, найважливіше що повинен зробити керівник, який бажає сформувати системи міжкультурних комунікацій, - це сформулювати для себе основні цінності організації $[3,4]$.

На формування системи міжкультурних комунікацій будь-якого підприємства впливає достатньо складна система чинників. Її можна розшарувати на три рівня: макрорівень (рівень суспільства), мезорівень (рівень організації) та мікрорівень (рівень особистості).

Проте процес міжкультурних комунікацій не $\epsilon$ статичною, постійно діючою формою взаємодії між суб'єктом надання послуг і споживачем в туризмі. Зміни в зовнішньому середовищі найчастіше спричиняють появу нових підходів до вирішення проблем, нових поведінкових стандартів, а іноді і до уточнення цінностей, яких дотримується організація, і виробленої філософії. Система міжкультурних комунікацій може бути розглянута також з суб'єктивного і об'єктивного боків. Суб'єктивні комунікації включають ряд елементів «символіки» : героїв організації, міфи, історії про організацію і пї лідерів, організаційні табу, обряди і ритуали, мову спілкування i гасла. Суб'єктивні комунікації служать основою формування управлінської культури, тобто стилю керівництва і вирішення проблем, поведінки керівництва в цілому.

Формування системи міжкультурних комунікацій передбачає тривалий і складний процес. Копіювання зарубіжних методів роботи в міжкультурному середовищі без урахування українських реалій і особливостей індивідуумів може мати значний негативний ефект, оскільки в роботі з людьми велике значення мають ментальність, традиції, особливості духовного й соціально-економічного середовища.

\section{Список використаних джерел}

1. Huxley, L. Western backpackers and the global experience: An exploration of young people's interactions with local cultures. Tour. Cult. Commun. 2004, 5, 37-44. 
2. Park, S. Effect of Multi-Cultural Family' Social Adjustment Ability on Satisfaction through Cultural Tourism: Focusing on Moderating Variable of Cultural Adjustment and Psychological Well-Being. Ph.D. Thesis, Graduate School, Tong Myong University, Busan, Korea, 2011.

3. Buonincontri, P.; Morvillo, A.; Okumus, F.; Niekerk, M. Managing the experience co-creation process in tourism destinations: Empirical findings from Naples. Tour. Manag. 2017, 62, 264-277.

4. Dedeoglu, B.; Bilgihan, A.; Ye, B.H.; Buonincontri, P.; Okumus, F. The impact of servicescape on hedonic value and behavioral intentions: The importance of previous experience. Int. J. Hosp. Manag. 2018, 72, 10-20. 